\title{
1. Various Actors: The Border Death Regime
}

\author{
Paolo Cuttitta, Jana Häberlein and Polly Pallister-Wilkins ${ }^{1}$
}

\begin{abstract}
Behind border deaths there is a variegated multiplicity of actors, guided by different principles and motivations, which contribute in different ways and to different extents to create the conditions for deaths to be more or less likely to occur or be prevented. Moreover, distinctive public and private actors enter the stage in the post-mortem phase. This chapter provides a tentative overview of the main categories of actors, showing the relationship different actors have with death, as well as with what could be seen as its counterpart: survival (from the survivors' perspective) or rescue (from the rescuers' perspective). The concluding section also proposes the concept of a 'border death regime' to make sense of this multitude of subjects.
\end{abstract}

Keywords: accidental actors, migrants and refugees, state and supra-state authorities, smugglers, NGOs and activists, changing roles

Who are the different actors involved in the social phenomenon of border deaths? What role do they play in causing and preventing migrant mortality, in making border deaths more or less likely to occur and more or less dependent on different variables, in highlighting or obscuring them? How far do border deaths, in turn, contribute to the multiplication and diversification of the actors involved?

Borders are social constructs. Their demarcation lines, as well as the way they are regulated (by specific policies) and operate in time and space (through specific practices), are the result of complex relationships between

1 The authors would like to thank Marthe Achtnich for her useful comments.

Cuttitta, P. \& Last, T. Border Deaths: Causes, Dynamics and Consequences of Migration-related Mortality. Amsterdam: Amsterdam University Press, 2020.

DOI: 10.5117/9789463722322_CHO1 
different state and non-state actors. Some of these actors (e.g. parliaments, governments, border enforcement agencies, international organizations, the border security industry etc.) could be seen as actors of control, as opposed to the actors of mobility that they try to discipline (e.g. people on the move and those who help them in their migratory projects: smugglers, activists etc.). However, actors often change and shift in their roles depending on the context (see Chapter 7).

Moreover, accidental actors come across border deaths only by chance (e.g. commercial vessels that happen to be involved in rescue operations at sea). They are not institutionally tasked with border enforcement, nor are they aimed at aiding migrants to cross borders. Further actors, such as nongovernmental organizations (NGOs), are not involved accidentally; however, they can't be easily categorized as supporting either border enforcement or border crossing. Finally, traffickers may not be seen as helping but rather as abusing migrants.

In sum, behind border deaths there is a variegated multiplicity of actors, guided by different principles and motivations, which contribute in different ways and to different extents to create the conditions for deaths to be more or less likely to occur or be prevented. Moreover, other public and private actors enter the stage in the post-mortem phase, when death has already occurred: coroners, civil servants, relatives and friends of dead or disappeared people, etc (see Chapters 2, 4 and 5).

This chapter provides a tentative overview of the main categories of actors, showing the relationship different actors have with death, as well as with what could be seen as its counterparts: survival (from the survivors' perspective) or rescue (from the rescuers' perspective). In the concluding section it also proposes the concept of a 'border death regime' to make sense of this multitude of subjects.

\section{Migrants}

Migrants who face the risk of border death are a complex category of people. They are individuals, but they often travel in groups; they rely to varying degrees on social support networks (relatives, friends, humanitarian aid providers, political activists, etc), as well as on professional service providers, such as smugglers and brokers (Alpes 2017); they make their own choices (to leave, when to do so, where to go, how), but these may be more or less autonomous, or more or less influenced by the choices and deeds of others, or by many human and non-human variables (e.g. wars, persecutions, natural 
disasters, weather conditions and other environmental and geographical concerns), with some being able to shape their migratory projects more freely, while others may be even physically forced to move across borders against their will (e.g. by traffickers or state authorities deporting them).

At different stages of their journeys (Collyer 2007; Mainwaring and Brigden 2016) they become irregularized, and sometimes criminalized, by state authorities, and mostly they are also commodified by diverse actors such as smugglers and corrupted representatives of state authorities, who detain and then sell them to other actors, or release them only after a ransom is paid.

Along their journeys, migrants come across different legal regimes in the different territories they transit, as well as different physical manifestations of the border, materializing in objects (e.g. walls, fences, patrol boats, visa offices), geomorphological barriers (e.g. the Alps) or human beings (e.g. border guards).

While many people are arguably dissuaded from migrating by the risk of death, and others start their journeys without a clear picture of the dangers they will face, many keep risking their lives in full awareness of what may happen to them. This also relates to the understanding of life and death that every individual migrant may have. For a returnee from the United States to Mexico, deportation was like death, so he was willing to risk his life trying to cross again: 'it is dying here or dying on the road trying, because you are already dead' (Humanizando la Deportación 2018).

Importantly, the risk of death turns those who complete a journey successfully into 'survivors'. This term - unlike definitions such as 'irregular' or 'illegal' - evokes humanitarian feelings of compassion; however, it does not evoke the idea of a recognition of rights besides that to life. Therefore, pretty much like 'irregular' or 'illegal', it contributes to a symbolic inferiorization of migrants.

\section{Migrants' relatives and friends}

Families and friends can play a role in the decision of migrants whether to leave or not, and then in supporting them in their journeys, in connecting them with professional smugglers or other facilitators. This may indirectly impact on the migrants' chances of dying en route or surviving their journeys.

Families and friends are affected by the deaths and disappearances of their relatives (Kovras and Robins 2016) and can also play a role in making incidents of border deaths public (see Chapters 5 and 6). For example, 
shipwrecks without survivors might remain unreported if the relatives do not announce the disappearance of their loved ones. Families can also advocate for justice, e.g. by asking state authorities to investigate the whereabouts of their relatives, or the causes of a specific death (Oliveri 2016).

\section{News Media}

The media is an important source of information on border deaths (see Chapter 2). Depending on a number of variables, some border deaths are hardly reported, if at all, while others make headlines worldwide. An important variable is where border deaths take place. Different degrees of freedom of the press, as well as the greater or more limited importance of migration in public debate, can result in border deaths being reported more in some countries and historical contexts while being obscured in others. Deciding which border death stories are newsworthy and which are not may also depend on who reports them (e.g. on their political motivations) (see Chapter 3).

Some border deaths remain unreported because the corpses were never found. Border deaths can also be deliberately hidden by the actors directly or indirectly responsible. ${ }^{2}$ Media investigations can unveil these unreported deaths. Media can also investigate into the responsibilities for specific border death cases. Finally, media plays a crucial role in how border deaths are represented (see Chapter 3 ) and thus perceived by the public.

\section{Researchers, artists, religious ministers etc.}

Like the media, other categories of actors can play a role in how border deaths are represented. Some examples are researchers (e.g. the authors of this book), artists (e.g. Ai Weiwei or the Center for Political Beauty), writers (e.g. Elfriede Jelinek or Erri De Luca) and religious ministers (e.g. father Mussie Zerai, Pope Francis) all of whom have expressly engaged with the issue of border deaths. Their work represents border deaths from specific (esthetical, moral, political) perspectives (see Chapter 3), foregrounding certain issues more (or rather) than others, and it may have differential impacts on policymakers and the wider public alike.

2 Dead bodies can be abandoned at sea (e.g. in the Mediterranean) or buried in mass graves (e.g. Rohingyas in Thailand) by smugglers or representatives of state authorities. 


\section{State authorities}

Representatives of different state bodies (also including supra-state entities such as the EU) may be involved in border deaths in different ways.

Policymakers - e.g. representatives of political parties, parliamentary assemblies and governments - make rules at the national level (e.g. by legislating laws and adopting administrative regulations) as well as at the international level (e.g. by signing and ratifying agreements and conventions), which can have different impacts on border deaths.

The imposition by governments of visa obligations is what creates irregular migration in the first place (Bigo and Guild 2003), and thus the conditions for people to risk their lives. More specifically, by imposing visa obligations on the citizens of given countries while exempting those of other countries, governments contribute to determining the national composition of the border dead population. Particular criteria for granting visas (e.g. a minimum income level for a tourist visa) further impacts on the composition of the border dead population from the perspective of social conditions, with the poor and the unemployed being by far more exposed to the risk of dying a border death.

Parliaments and governments are also responsible for the establishment of border walls and fences, which may directly cause border deaths or divert migrants to alternative - and more or less deadly - routes. Policymakers also establish detention centres and other border-related facilities, and they introduce and regulate legal institutions (e.g. expulsions and forced returns), which may happen to cause border deaths, either directly (e.g. people dying because of a disproportionate use of force while being deported) or indirectly (e.g. people committing suicide for fear of being deported).

Governments of countries of destination, origin and transit make international agreements on police and judiciary cooperation aimed at preventing unauthorized departures. The resulting increased surveillance and repression may discourage migrants from leaving or continuing their journeys, or push them to take other, more dangerous routes. The same considerations apply to the laws passed by parliaments to criminalize activities facilitating irregular migration. These measures address service providers such as carriers and smugglers, and sometimes even NGOs and individuals providing search and rescue (SAR) services or other forms of humanitarian support (Fekete, Webber and Edmond-Pettitt 2017, 2019; Vosyliūtè and Conte 2018).

The judiciary has the task of determining which actors should be held responsible for specific border death cases. More generally, court decisions - at 
both national and international level ${ }^{3}$ - may decide whether specific practices of border control or SAR are lawful or unlawful. Thus, they can impact on the choices of migrants and smugglers regarding the routes and logistics of the journeys, and, indirectly, on the travellers' chances of dying or surviving.

State authorities are increasingly involved in activities aimed at preventing border deaths, directly or indirectly.

Indirectly, they promote information campaigns for (would-be) migrants in countries of transit and origin. By informing the beneficiaries about the relevant risks (including death), these campaigns aim to discourage them from embarking on irregular journeys. ${ }^{4}$ Furthermore, the national and international legislative, police and judiciary activity against smuggling and trafficking is increasingly presented and justified as being aimed at preventing deaths (Cusumano 2018; Cuttitta 2018b; Pallister-Wilkins 2015).

Directly, state authorities can engage in proactive humanitarian operations tasked with SAR (as Italy, Germany and Ireland did in the Central Mediterranean in different periods between 2013 and 2017) or schemes aimed at tracing missing migrants and identifying bodies (as Honduras has been doing since 2015).

Moreover, coastal states run Maritime Rescue Coordination Centres (MRCC) which are responsible for coordinating SAR operations in the relevant state's SAR region in international waters. However, some MRCCs have been accused of putting migrants in danger by ignoring distress cases or by not informing private rescue vessels of a distress case (Tonacci 2018).

Similarly, while state authorities engaged in border control can be agents of rescue, they can also be directly responsible for specific cases of death (e.g. people shot dead by border guards at the Spanish-Moroccan or Egyptian-Israeli border) or pave the way for deaths to occur as a result of their conduct (La Coalición de Derechos Humanos and No More Deaths 2016). The way border enforcement agencies ${ }^{5}$ are trained and equipped, as well as the decisions about how many assets and staff to deploy, and where, may significantly contribute to causing or preventing border deaths. As street-level bureaucrats, border guards may exercise considerable discretion when taking decisions (Häberlein 2019; Lipsky 1969). While they often end up rescuing people who would lose their lives if not intercepted, they sometimes fail to respond to emergency situations (La Coalición de Derechos Humanos and No More Deaths forthcoming) or to

3 An example of an international court is the European Court of Human Rights.

4 Research has questioned the effectiveness of these schemes (Rodriguez 2019).

5 Border enforcement may be delegated to specific agencies of border guards or to the police, the military, the coast guard and/or other security agencies. 
intervene when they spot migrants in distress (Strik 2012). In some cases, border enforcement agencies also interfere with humanitarian organizations aimed at rescuing people, e.g. by destroying water canisters placed in the desert (La Coalición de Derechos Humanos and No More Deaths 2018) or intimidating and harassing humanitarian volunteers (Cuttitta 2018a).

Processes of neglect or violence by state authorities may also contribute to border deaths in detention centres and other border facilities. Finally, some representatives of some state authorities, such as the Libyan Coast Guard, are directly involved in smuggling activities (UN 2017) and thus contribute to making potentially deadly journeys possible.

In the post-mortem phase, public authorities (police, the public health system, coroners, municipal registrars, courts, cemetery attendants, etc) are involved in identifying dead bodies, determining the cause of death, doing autopsies, taking DNA samples, collecting and registering data, contacting the relatives, organizing the burial or the repatriation of the corpse, or assisting injured and traumatized survivors (Chapter 4; see also Last et al 2017). The consular authorities of origin countries can also become involved in these processes.

\section{The border security industry}

The security industry creates the conditions for border controls to evolve and be carried out with the support of the most updated and effective technologies (Gammeltoft-Hansen and Nyberg-Sørensen 2012; Sontowski 2016). The border security industry does not only respond to the demand from policymakers by offering solutions for specific problems: its offer may also contribute to shaping the demand (Baird 2018), and thus to design border control policies. It thus plays an indirect role in the deadly effects of the latter. However, its technologies can also be used to enhance SAR capacities of both state and non-state actors.

\section{International and intergovernmental organizations}

International organizations (IOs) and intergovernmental organizations (IGOs) cooperate with governments of countries of destination, transit and origin as both advisors and implementing partners. As the substantive part of their budget comes from rich destination countries (through state-funded projects or donations), they have only limited autonomy and leverage towards 
them, and are often regarded as instruments for the implementation of their policies, most notably within the process of externalization to countries of origin and transit (Lavenex 2016).

The United Nations High Commissioner for Refugees (UNHCR) and the International Organization for Migration (IOM) are the main migrationrelated IO and IGO, respectively.

UNHCR promotes humanitarian corridors, complementary pathways, and resettlement schemes which provide alternatives to irregular journeys for refugees. It also tries to pressure governments not to adopt border policies that may put lives at risk. Finally, it can be involved in assisting refugees in post-mortem issues.

IOM is particularly involved in awareness campaigns in countries of origin and transit, informing people about the risks of irregular migration. IOM also carries out so-called search and rescue missions in the Sahara, in cooperation with the Nigerian authorities, which are at the same time diffused border patrol operations (IOM 2017). Finally, IOM is engaged in collecting data about border deaths through its Missing Migrants Project (Al Tamimi et al forthcoming; see also Chapters 2 and 4).

Other IOs and IGOs, while not having migration or asylum as their primary fields of action, may also be involved in activities directly or indirectly related to border deaths. ${ }^{6}$

In some regions of the world, IOs and IGOs have to make up for the insufficient capacities of state authorities and the lack or scarcity of other actors. There, they are often confronted with issues that go beyond their mandate, also including issues related to border deaths. ${ }^{7}$

\section{NGOs/CSOs}

The categories 'NGO' (non-governmental organization) and 'CSO' (civil society organization) are not easily distinguishable from one another. They are also far from homogeneous in terms of their activities, aims, ethical and political positionings, funding sources, and degree of independence from public authorities.

6 Examples are Interpol, the International Commission on Missing Persons (ICMP), as well as diverse UN agencies such as the United Nations Children's Fund (UNICEF), the Office of the United Nations High Commissioner for Human Rights (OHCHR), and the United Nations Office on Drugs and Crime (UNODC). For various initiatives see Chapters 2, 3, 4, 5 and 8.

7 In Egypt, for example, UNHCR has been involved in the identification of unknown dead bodies that were presumed to be of migrants. 
Large NGOs that have been traditionally close to public authorities are the International Red Cross and the Red Crescent movement. The National Red Cross and Red Crescent Societies are often involved in processes of identification, burial and contact with the relatives of the deceased. By definition, they have an auxiliary role to state authorities. The International Committee of the Red Cross has promoted the project Restoring Family Links, to help relatives of missing migrants find out whether their loved ones are still alive and to re-establish contact with them. Other activities by ICRC and national societies are aimed at preventing border deaths, e.g. by offering courses on SAR, providing medical aid at points of disembarkation of migrants or even on the high seas. ${ }^{8}$

Similarly, many international and local, large and small NGOs/CSOs limit themselves to mere humanitarian assistance, and act in close cooperation with states, often within state-funded projects.

More politically motivated NGOs and CSOs and activist networks define their activities related to border deaths as going beyond the provision of humanitarian aid and as a means to contest state policies and practices. While SAR NGOs carrying out rescue operations at sea or supporting these are primarily concerned with rescuing people, some of them (e.g. Sea-Watch and Watch the Med Alarm Phone) also use the issue of border deaths to criticise current migration policies and practices, in an attempt to repoliticize the border (Cuttitta 2018a; Stierl 2018). Their (mostly privately funded) activities are understood to be a form of counter-surveillance (Dijstelbloem 2017; Stierl 2016). Meanwhile right-wing, xenophobic campaigns step in precisely to harass SAR NGOs: for instance, in 2017, the Generation Identity movement's 'Defend Europe' mission in the Mediterranean, supported the defamation and criminalization campaign against NGOs which led to the overall reduction of SAR capacities in the Central Mediterranean. Other CSOs (e.g. the Minutemen at the US-Mexico border) engage in reporting and denouncing migrants trying to cross the border, which can result in migrants taking alternative, more dangerous routes, or dying while attempting to escape from interception by border guards alerted by citizens.

More generally, and regardless of their political attitude, a wide and diverse range of NGOs/CSOs are formally or informally involved in activities related to border deaths, e.g. collecting data, helping survivors recovering from facing border deaths, reporting and locating missing persons, ensuring that the dead get appropriate burials, etc. ${ }^{9}$

8 In support of the Italian Navy in 2013-2014 and of the Maritime Offshore Aid Station (MOAS) in 2016.

9 For various initiatives see Chapters 2, 3, 4, 5 and 8. 


\section{Carriers}

The companies providing passenger transportation services over land, sea and air have long been subject to specific laws which impose sanctions on them if they carry undocumented or improperly documented passengers. To avoid sanctions, carriers refuse to take people on board who do not comply with the rules about entry in the countries of transit and destination. As a consequence, those who cannot or do not want to give up their migratory project have to travel irregularly. Although refugees have the right to enter any country, and carriers are exempted from sanctions if the undocumented persons they carry are then recognized as refugees, carriers generally refuse to take on board asylum seekers at the point of embarkation because they don't know whether asylum will be granted or not (Feller 1989). Even those who have the right to cross borders are thus prevented from reaching those very borders regularly, and have no other choice but to risk their lives. This is possibly the most vivid example of how (the risk of) death may be caused indirectly by the combination and intersection of interests, legal regimes and actions of different agents, rather than directly by the action or inaction of a specific actor.

\section{Smugglers}

The irregularization of migration through restrictive legislation by a growing number of countries worldwide has resulted in the global rise of the migrant smuggling industry.

Smugglers are known to the wider public for the violence and abuses inflicted on migrants during all stages of the journeys. Many, indeed, abandon people in the desert, let them starve in detention (in so-called 'connection houses') while waiting for the next stage of their journey, shoot them dead if they try to escape, force them to board unseaworthy boats, throw them into the water if they don't obey their orders or are believed to bring bad luck during sea crossings, etc. ${ }^{10}$

However, border deaths also occur as a result of the changed tactics of smugglers regarding travel logistics, which are made in response to changes in policies and practices by state authorities aimed at trying to stop them

10 In so doing, they challenge the distinction between smugglers and traffickers made by the Palermo protocols supplementing the United Nations Convention against Transnational Organized Crime. For a reflection on the uncritical use of this distinction see Baird (2016). 
(Brachet 2018). For example, in 2015 smugglers operating on the Libya-Italy route replaced the safer (but more expensive) wooden boats with cheaper and unseaworthy dinghies when the EU mission EUNAVFOR Med started destroying all vessels (thus making their reuse impossible) after each rescue operation. Consequently, a measure that was aimed at deterring smugglers, ended up only harming the migrants, who were forced to travel less safely.

Smuggling doesn't necessarily imply a high risk of death. Good smugglers, providing reliable travel services, can even be seen as saviours of lives, insofar as they protect their customers from the death risks associated with alternative travel solutions.

Like state authorities, smugglers can also contribute to making the likelihood of dying a border death dependent on the migrants' social status. For those who can afford higher fees, they sell falsified or forged documents, and organize journeys with regular - and safe - carriers. For the poor, smugglers offer riskier solutions, which may be more or less dangerous depending on the financial status or ethnic origin of travellers: for sea crossings to Europe on fishing boats, for example, Arabs typically have to pay the full price and travel on the deck, while Sub-Saharan Africans pay less to be transported in the hold (Ciavoni 2015), thus running the additional risk of dying of suffocation or being unable to escape in case of a shipwreck (Viviano and Ziniti 2016).

\section{Other private actors}

Unlike SAR NGOs, which have the explicit aim of assisting migrants, other civilians (individuals or groups) may come across migrants in distress just by accident. For example, commercial vessels have often been involved in rescue operations. Some of these operations end up as tragedies because cargo ships are not specifically equipped or trained for SAR (Heller and Pezzani 2016). Furthermore, since rescue operations require a lot of time, they result in heavy economic losses for ship owners. Therefore, some commercial vessels take alternative routes or turn off their automatic identification systems, thus becoming invisible to the authorities coordinating SAR. This results in a reduction of SAR capacities, and an increased risk for migrants.

Local people can also be involved in a range of ways. Some happen to participate in rescue operations because they witness a shipwreck on the coast (Candito 2019). In border regions, some provide basic needs for people transiting there, or even help them to find the safest way to cross the border (Papataxiarchis 2016a and 2016b). Others engage in anti-migration activities instead, such as destroying water canisters placed by humanitarian 
volunteers in the desert along the US-Mexico border (La Coalición de Derechos Humanos and No More Deaths 2018). In Egypt, criminal organizations have bought migrants from smugglers and killed them after extracting and selling their organs (Moore 2016).

\section{The Border Death Regime}

Scholars have used the notion of 'regime' (Horvath et al 2017; Pott et al 2018) to conceptualize a 'migration and border regime'. In this sense, regime refers to 'a social, conflictual process of negotiation on diverse scales and with a multitude of involved actors' (Hess 2012: 430) whose practices, 'while related, are not organized in terms of a central logic, but are multiply overdetermined' (Papadopoulos et al 2008: 164). Importantly, these practices always keep the regime in a process of transformation: 'the life of a regime is the result of continuous repair work through practices' (Sciortino 2004: 32-33). Adopting the regime perspective allows for the investigation of 'the set of heterogeneous social practices and structures, of discourses, actors, and rationalities that intervene in processes of governmentalization of the border' (Mezzadra and Neilson 2013: 179).

The multiplicity and heterogeneity of the actors described in this chapter could be seen as the human (and living) component of what could be called a 'border death regime'. Indeed, border deaths occur in highly complex and contested contexts, in which a panoply of actors interact through diverse policies, practices, and discourses, and the diversity of aims, motivations and roles between the different actors is visible not only across the different categories of actors listed above but also within each of them.

This chapter has shown that death has transformed the composition and dynamics of the border regime by creating the conditions for new actors to step in (SAR NGOs, private individuals, etc) as well as by transforming the position of other actors and the way they relate their activities to border deaths (e.g. state authorities launching SAR operations and presenting their migration and border policies as being aimed at preventing deaths).

While it generates a form of systemic violence 'that is diffused and dispersed among many actors' (Heller and Pezzani 2014: 659), the border death regime seems to perpetuate itself: ${ }^{11}$ on the one hand, different border

11 Spijkerboer (Afterword) and Dijstelbloem, Horn and Jarvis (Chapter 8) propose solutions for breaking this self-perpetuating cycle between policy and deaths. Holding states to account (Chapters 4 and 6) may also disrupt the regime enough to end this form of structural violence. 
actors create new opportunities for death and rescue to occur and take centre stage; on the other hand, death and rescue contribute to multiplying and diversifying the actors involved, as well as to transforming their policies, practices and discourses.

\section{References}

Alpes, Maybritt Jill. 2017. 'Why Aspiring Migrants Trust Migration Brokers: The Moral Economy of Departure in Anglophone Cameroon.' Africa 87 (2), 304-321. Al Tamimi, Yussef, Paolo Cuttitta and Tamara K. Last. Forthcoming. 'The Missing Migrants Project: The Global Authority on Border Deaths Data.' In: International Organization for Migration (IOM). The New 'UN Migration Agency' in Critical Perspective, edited by Martin Geiger and Antoine Pécoud. Basingstoke: Palgrave Macmillan.

Baird, Theodore. 2018. 'Interest Groups and Strategic Constructivism: Business Actors and Border Security Policies in the European Union.' Journal of Ethnic and Migration Studies 44 (1), 118-136.

Baird, Theodore. 2016. 'Defining Human Smuggling in Migration Research: An Appraisal and Critique.' EUI Working Paper (RSCAS 2016/30).

Bigo, Didier, and Elspeth Guild. 2003. 'Le visa Schengen: expression d'une stratégie de "police" à distance.' Cultures \& Conflits 49, 22-37.

Brachet, Julien. 2018. 'Manufacturing Smugglers: From Irregular to Clandestine Mobility in the Sahara.' Annals of the American Academy of Political and Social Science 676 (March), 16-35.

Candito, Alessia. 2019. 'Migranti, in 51 su barca incagliata: li salvano i cittadini.' La Repubblica (10 January 2019). https://www.repubblica.it/cronaca/2019/01/10/ news/migranti_in_51_su_barca_incagliata_li_salvano_i_cittadini-216232154/ (accessed 5 May 2019)

Ciavoni, Carlo. 2015. 'I sub sahariani nella stiva, il mondo fatto a strati anche nelle barche dei migranti.' La Repubblica (20 April 2015). https://www.repubblica.it/ solidarieta/emergenza/2015/04/20/news/oim-112443667/ (accessed 5 May 2019)

Collyer, Michael. 2007. 'In-Between Places: Trans-Saharan Transit Migrants in Morocco and the Fragmented Journey to Europe.' Antipode 39 (4), 668-69o.

Cusumano, Eugenio. 2019. 'Migrant Rescue as Organized Hypocrisy. EU Maritime Missions Offshore Libya Between Humanitarianism and Border Control.' Cooperation and Conflict 54 (1), 3-24.

Cuttitta, Paolo. 2018a. 'Repoliticization Through Search and Rescue? Humanitarian NGOs and Migration Management in the Central Mediterranean.' Geopolitics 23 (3), 632-66o. 
Cuttitta, Paolo. 2018b. 'Delocalization, Humanitarianism and Human Rights: The Mediterranean Border Between Exclusion and Inclusion.' Antipode $5^{\circ}$ (3), $783-803$.

Dijstelbloem, Huub. 2017. 'Migration Tracking is a Mess.' Nature 543 (March), 32-34.

Fekete, Liz, Frances Webber, and Anya Edmond-Pettitt. 2019. When witnesses won't be silenced: citizens' solidarity and criminalisation. London: Institute of Race Relations.

Fekete, Liz, Frances Webber, and Anya Edmond-Pettitt. 2017. Humanitarianism. The Inacceptable Face of Solidarity. London: Institute of Race Relations.

Feller, Erika. 1989. 'Carrier Sanctions and International Law.' International Journal of Refugee Law 1 (1), 48-66.

Gammeltoft-Hansen, Thomas, and Ninna Nyberg Sørensen (eds.). 2012. The Migration Industry and the Commercialization of International Migration. London: Routledge.

Häberlein, Jana. 2019. 'The Vitality of Borders. Migration Through and Bordering Practices in Switzerland.' In: Changing Landscapes. Switzerland and Migration, edited by Barbara Lüthi and Damir Skenderovic. Basingstoke: Palgrave Macmillan.

Heller, Charles, and Lorenzo Pezzani. 2016. 'Main Narrative.' In: Death by Rescue. https://deathbyrescue.org/report/narrative/ (accessed 5 May 2019)

Heller, Charles, and Lorenzo Pezzani. 2014. 'Liquid Traces: Investigating the Deaths of Migrants at the EU's Maritime Frontier.' In: Forensis. The Architecture of Public Truth, by Forensic Architecture. Berlin: Sternberg Press.

Hess, Sabine. 2012. 'De-naturalising Transit Migration. Theory and Methods of an Ethnographic Regime Analysis.' Population, Space and Place 18, 428-440.

Horvath, Kenneth, Anna Amelina, and Karin Peters. 2017. 'Re-thinking the Politics of Migration. On the Uses and Challenges of Regime Perspectives for Migration Research.' Migration Studies 5 (3), 301-314.

Humanizando la Deportación. 2018. 'Sudden Death.' http://humanizandoladeportacion.ucdavis.edu/en/2018/og/22/76-sudden-death/ (accessed 5 May 2019) International Organization for Migration (IOM). 2017. 'UN Migration Agency Search and Rescue Missions in Sahara Desert Help 1,ooo Migrants.' IOM News (8 August 2017). https://www.iom.int/news/un-migration-agency-search-andrescue-missions-sahara-desert-help-10oo-migrants (accessed 5 May 2019)

Kovras, Iosif, and Simon Robins. 2016. 'Death as the Border: Managing Missing Migrants and Unidentified Bodies at the EU's Mediterranean Frontier.' Political Geography 55, 40-49.

La Coalición de Derechos Humanos and No More Deaths. Forthcoming. 'Disappeared. How the US border enforcement agencies are fueling a missing persons 
crisis. Part III: Emergency Nonresponse.' The Disappeared report series. To be published on http://www.thedisappearedreport.org.

La Coalición de Derechos Humanos and No More Deaths. 2018. 'Disappeared. How the US Border Enforcement Agencies Are Fueling a Missing Persons Crisis. Part II: Destruction of and Interference with Humanitarian Aid.' The Disappeared report series. http://www.thedisappearedreport.org/uploads/8/3/5/1/83515082/ disappeared_report_part_2.pdf(accessed 5 May 2019)

La Coalición de Derechos Humanos and No More Deaths. 2016. 'Disappeared. How the US Border Enforcement Agencies Are Fueling a Missing Persons Crisis. Part I: Deadly Apprehension Methods.' The Disappeared report series. http://www. thedisappearedreport.org/uploads/8/3/5/1/83515082/fianlparti.pdf (accessed 5 May 2019)

Last, Tamara, Giorgia Mirto, Orçun Ulusoy, Ignacio Urquijo, Joke Harte, Nefeli Bami, Marta Pérez Pérez, Flor Macias Delgado, Amélie Tapella, Alexandra Michalaki, Eirini Michalitsi, Efi Latsoudi, Naya Tselepi, Marios Chatziprokopiou and Thomas Spijkerboer. 2017. 'Deaths at the Borders Database: Evidence of Deceased Migrants' Bodies Found Along the Southern External Borders of the European Union.' Journal of Ethnic and Migration Studies 43 (5), 693-712.

Lavenex, Sandra. 2016. 'Multilevelling EU External Governance: The Role of International Organizations in the Diffusion of EU Migration Policies.' Journal of Ethnic and Migration Studies 42 (4), 554-570.

Lipsky, Michael. 1969. 'Toward a Theory of Street-Level Bureaucracy.' Institute for Research on Poverty Discussion Papers. University of Wisconsin-Madison. https:// www.irp.wisc.edu/publications/dps/pdfs/dp4869.pdf (accessed 5 May 2019)

Mainwaring, Ċetta, and Noelle Brigden. 2016. 'Beyond the Border: Clandestine Migration Journeys.' Geopolitics 21 (2), 243-262.

Mezzadra, Sandro, and Brett Neilson. 2013. Border as Method, or, the Multiplication of Labor. Durham/London: Duke University Press.

Moore, Jack. 2016. 'African Migrants Are “Being Sold for Their Organs”.' Newsweek (5 July 2016). https://www.newsweek.com/migrants-are-being-sold-their-organsclaims-former-trafficker-477635 (accessed 5 May 2019)

Oliveri, Federico. 2016. “Where Are Our Sons?” Tunisian Families and the Repoliticization of Deadly Migration Across the Mediterranean Sea.' In: Migration by Boat: Discourses of Trauma, Exclusion and Survival, edited by Linda Mannik, pp. 154-177. New York: Berghahn Books.

Pallister-Wilkins, Polly. 2015. 'The Humanitarian Politics of European Border Policing: Frontex and Border Police in Evros.' International Political Sociology 9 (1), 53-69.

Papadopoulos, Dimitris, Niamh Stephenson and Vassilis Tsianos. 2008. Escape Routes. Control and Subversion in the Twenty-first Century. London: Pluto. 
Papataxiarchis, Evthymios. 2016a. 'Being "there": At the Front Line of the "European Refugee Crisis” - Part 1.' Anthropology Today 32 (2), 5-9.

Papataxiarchis, Evthymios. 2016b. 'Being "there”: At the Front Line of the "European Refugee Crisis" - Part 2.' Anthropology Today 32 (3), 3-7.

Pott, Andreas, Christoph Rass, and Frank Wolff (eds.). 2018. Was ist ein Migrationsregime? What is a Migration Regime? Wiesbaden: Springer VS.

Rodriguez, Anne-Line. 2019. 'European Attempts to Govern African Youths by Raising Awareness of the Risks of Migration: Ethnography of an Encounter.' Journal of Ethnic and Migration Studies 45 (5), 735-751.

Sciortino, Giuseppe. 2004. 'Between Phantoms and Necessary Evils. Some Critical Points in the Study of Irregular Migrations to Western Europe.' Imis-Beiträge 24, 17-44.

Sontowski, Simon. 2016. “Testing the Borders of the Future”. Einblicke in die umkämpfte Entstehung der EU-Smart-Border.' In:Nach der Migration. Soziale Rechte ohne Grenzen, edited by Hans Baumann, Roland Herzog, Marina Richter, Beat Ringger, Sarah Schilliger, Holger Schatz, Bernhard Walpen (Denknetz-Jahrbuch 2016), pp. 59-66. Zürich: Edition 8.

Stierl, Maurice. 2018. 'A Fleet of Mediterranean Border Humanitarians.' Antipode $50(3), 704-724$.

Stierl, Maurice. 2016. 'A Sea of Struggle - Activist Border Interventions in the Mediterranean Sea.' Citizenship Studies 20 (5), 561-578.

Strik, Tineke. 2012. Lives lost in the Mediterranean Sea: who is responsible? Report to the Parliamentary Assembly, Council of Europe. (29 March 2012). http://assembly. coe.int/CommitteeDocs/2012/20120329_mig_RPT.EN.pdf(accessed 5 May 2019)

Tonacci, Fabio. 2018. 'I salvataggifantasma che non arrivano alla “Mare Jonio”.' La Repubblica (7 November 2018). https://www.repubblica.it/cronaca/2018/11/o7/ news/salvataggi_fantasma-210995585/?ref=RHPPBT-BH-Io-C4-P6-S1.4-T1 (accessed 5 May 2019)

United Nations (UN). 2017. Final report of the Panel of Experts on Libya established pursuant to resolution 1973 (2011) (1 June 2017). https://reliefweb.int/sites/reliefweb. int/files/resources/N1711623.pdf (accessed 5 May 2019)

Viviano, Francesco, and Alessandra Ziniti. 2016. 'I corpi dei migranti aggrediti dai pesci, recuperate sei salme da un barcone affondato l'anno scorso davanti la Libia.' La Repubblica (27 June 2016). https://palermo.repubblica.it/cronaca/2016/o6/27/ news/recuperate_sei_salme_da_un_barcone_affondato_l_anno_scorso_davanti_la_libia-142906914/(accessed 5 May 2019)

Vosyliūtè, Lina, and Carmine Conte. 2018. 'Crackdown on NGOs Assisting Refugees and Other Migrants.' Resoma Discussion Brief, July. http://www.resoma.eu/sites/ resoma/resoma/files/policy_brief/pdf/Policy\%2oBriefs_topic4_Crackdown\%20 on\%2oNGOs_o.pdf (accessed 12 July 2019) 


\section{About the authors}

Paolo Cuttitta is a Marie Curie fellow at the Centre de Recherche sur l'Action Locale, Université Paris 13. He previously worked at Vrije Universiteit Amsterdam and Palermo University. His current research looks at humanitarian border management and the changing roles of state and non-state actors in the EU/North African border regime.

Jana Häberlein is a sociologist and an associated researcher in the SNISproject, Infrastructure Space and the Future of Migration Management: The EU Hotspots in the Mediterranean Borderscape, at Basel University. Previously, she was a visiting scholar at the University of California, Davis (2017) and a postdoc at Neuchâtel University (2014-2017).

Polly Pallister-Wilkins is an Assistant Professor in political science at the University of Amsterdam. Her research looks at the intersection of border controls and humanitarianism, something she calls humanitarian borderwork. She is a principal researcher in the Horizon 2020 project, ADMIGOV: Advancing Alternative Migration Governance, looking at humanitarian protection issues. 
